\title{
Regarding the publication of case reports
}

\section{René Agustín Flores-Franco}

Instituto Mexicano del Seguro Social, Hospital General Regional de Zona 1, Unidad "Morelos", Department of Internal Medicine, Chihuahua, Chihuahua, Mexico

I have read with interest the recently published editorial article by Dr. Rodríguez-Velasco, ${ }^{1}$ where she rightly defends the publication of case reports in medical journals. In that regard, I would like to elaborate on her comments.

I am not a researcher myself and my ability as such would be only that which I pursue during my daily clinical practice when applying the scientific method during medical examination of patients. In the specific section of medical journals where case reports are included, non-researcher doctors have the opportunity to express ourselves. The purpose of any investigation is to solve a problem, and to do it, a quantitative methodology is not necessarily used. Many aspects of professional and personal life cannot be explained solely with numbers or based on evidence. The qualitative methodology to address a problem is extremely humanistic and focuses on how the individual perceives his or her experiences and beliefs and how his or her interactions with others influence on those attitudes and values. ${ }^{2}$

A qualitative researcher interprets situations with descriptions and personal considerations with the sole purpose to acquire a better understanding of a particular human condition, taking into account the natural setting where it develops by means of an inductive analysis. ${ }^{2}$ This is precisely the methodology used in case reports and the basic principle of a current trend towards the practice of a behavioral medicine. ${ }^{3}$

Case reports are an ideal complement to quantitative research because they put its results into practice in real environments. Therefore, I consider unfair for case reports not to be weighted similarly as information obtained by a quantitative investigation. A scientific publication with validity requires evaluation by reviewers who are experts in the subject, organized information that includes a hypothesis, a methodology and an analysis of results, and to be expressed in a particular format in journals. ${ }^{4}$ All these elements are considered in the publication of case reports.

\section{References}

1. Rodríguez-Velasco A. El dilema de los editores: ¿debe o no aceptarse el reporte de casos para publicación? Gac Med Mex 2018;154:149-151.

2. Pitney WA, Parker J. Qualitative research in physical activity and the health professions. EE.UU.: Human Kinetics; 2009.

3. Feldman MD, Christensen JF. Behavioral medicine: a guide for clinical practice. EE.UU.: McGraw-Hill; 2014.

4. Matthews JR, Matthews RW. Successful scientific writing. A step-by-step guide for the biological and medical sciences. EE.UU.: Cambridge University Press; 2008.
Gac Med Mex. 2018;154:423-423

Contents available at PubMed www.gacetamedicademexico.com 